АКТИВІЗАЦІЯ ПІЗНАВАЛЬНОЇ АКТИВНОСТІ УЧНІВ НА УРОКАХ УКРАЇНСЬКОЇ ТА ЗАРУБІЖНОЇ ЛІТЕРАТУРИ ЗАСОБАМИ МУЛЬТИМЕДІЙНИХ ТЕХНОЛОГІЙ

\title{
ENHANCING STUDENTS' COGNITIVE ACTIVITY IN THE LESSONS OF UKRAINIAN AND FOREIGN LITERATURE BY MEANS OF MULTIMEDIA TECHNOLOGIES
}

Модернізація освіти зумовлює зростання ролі застосування мультимедійних технологій в освітньому процесі. Учитель, за винятком використання у процесі організації навчального процесу традиційних фрорм і методів навчання, має обов'язок проєктувати навчальне й освітнє середовище із залученням сучасних інфрормаційних, комп'ютерних і педагогічних інновацій. Сьогодні в педагогічну практику запроваджується досить новий етап комп'ютеризаціі низки наукових дисциплін, який спровокований розвитком мультимедійних технологій. В інтерактивному режимі роботи анімації, графріки, фото- й відеоматеріали, звукові та текстові матеріали формують інтегроване інорормаційне середовище, у якому користувач одержує якісно нові можливості, що виконують роль вагомого засобу до здійснення активізації навчально-пізнавальної діяльності учнів. Мультимедійні засоби навчання на уроках української та зарубіжної літератури не можуть замінити вчителя, однак вони впливатимуть на вдосконалення и урізноманітнення діяльності педагога що своєю чергою дасть змогу підвищити рівень продуктивності освітнього процесу. Використання мультимедійних технологій у процесі навчання літератури дасть можливість ширше та повноцінно представити творчий потенціал кожного з учнів. Мультимедійні засоби в освітньому процесі можуть бути представлені в електронних підручниках, самостійно підготовленому вчителем матеріалі, у вигляді презентаuії інсрормації з використанням при цьому програми PowerPoint, за допомогою відеометодів, електронної пошти, проведення рольових ігор, використання електронних інтерактивних дошок тощо. Упровадження мультимедійних засобів у навчальний прочес дасть можливість дещо видозмінити характер навчально-пізнавальної діяльності учнів та покращити активізацію їхньої самостійної роботи за допомогою використання електронних засобів, призначених для навчання. Одним із таких ефрективних засобів є мультимедіа, які дають змогу учням оволодіти первинними знаннями. Потениійні переваги інфрормаційних технологій полягають у можливості формувати модульні, легко пристосовувані до потреб певного користувача навчальні програми, причому незалежно від часу та місия навчання. Таким чином, використання мультимедійних технологій у навчальному процесі дасть можливість покращити навчання, зробити його більш індивідуалізованим та ефективним. Однією з особливостей навчального процесу, у якому використано мультимедіа, $\epsilon$ наявність інтересу до навчання, вплив на активізацію й концентрування уваги учнів на предметі, підвищення пізнавальної актив ності учнів на уроках української та зарубіжної літератури.

Ключові слова: інформаційні інновації, комунікативна компетентність, мультиме діа, мультимедійні технології, пізнавальна активність

Updating education leads to an increasing role of multimedia technologies in the educational process. In addition to the use of traditional teaching forms and methods when organizing the educational process, the teacher must design the educational and learning environment with the involvement of modern information, computer and pedagogical innovations. Today, a new stage of computerization in various scientific disciplines caused by the development of multimedia technologies is being introduced into pedagogical practice. In the interactive mode graphics, animation, photos, videos, sound and tex create an integrated information environment in which the user finds qualitatively new opportunities that can play a significant role in enhancing students' educational and cognitive activities. Multimedia teaching aids in Ukrainian and foreign literature lessons cannot replace a teacher but they will contribute to improving and diversifying the teacher's activity, which should increase the productivity of the educational process. The use of multimedia technologies in the process of teaching literature allows revealing more widely and fully the creative potential of each student. Multimedia tools in the educational process can be presented in electronic textbooks, toolkits prepared by the teacher, PowerPoint presentations, video method, e-mails, role-playing games, electronic interactive whiteboards etc The use of multimedia tools in the educational process allows changing the nature of students' educational and cognitive activities, intensifying independent work with various electronic educational tools. The most effective one is the use of multimedia when students master primary knowledge. There are potential advantages of information technology, for example, the ability to create training programs which are modular and easily adapted to the needs of a particular user and don't depend on the place and time of study. Thus, the use of multimedia technologies allows teachers to make learning more effective and individualized. The peculiarity of the learning process by means of multimedia arouses interest in learning and promotes students' enhancing and concentrating on the subject, increasing their cognitive activity in lessons of Ukrainian and foreign literature.

Key words: information innovations, communicative competence, multimedia, multimedia technologies, cognitive activity. 
Постановка проблеми в загальному вигляді. Упровадження сучасних інформаційних технологій на заняттях з української та зарубіжної літератури є однією з актуальних проблем сучасної методики викладання цих предметів. Мультимедійні засоби сьогодні $€$ невід'ємною частиною процесу навчання. В умовах сьогодення педагог повинен уміти користуватися сучасними засобами навчання. Зокрема, йому це необхідно для того, щоб забезпечити дотримання одного з найголовніших прав здобувача освіти - права на здобуття якісної освіти. Належне оснащення кабінету, у якому проводитиметься навчання учнів, комп'ютерною технікою, а також доцільне використання цієї техніки на заняттях з української і зарубіжної літератури сьогодні є обов'язковим атрибутом закладів загальної середньої освіти.

Уроки з використанням комп'ютера фрормують в учнів підвищений пізнавальний інтерес і творчу активність. Використання комп'ютерних технологій у навчальному процесі дає педагогу можливість реалізувати особистісний підхід до побудови навчального процесу, а також розробляти й упроваджувати поетапне застосування знань, умінь і навичок. На таких засадах відбувається краще сприйняття та легше запам'ятовування навчального матеріалу з економним використанням часу при цьому. Індивідуальний підхід, поєднуючись із поточним контролем, дає змогу максимально об'єктивно оцінити й ефективно управляти процесом засвоєння нової теми. Контролювання в такому процесі має зворотний зв'язок, як і діагностика помилок результатів навчання. У цьому процесі має місце також фрормування готовності особистості до творчої діяльності. Зокрема, використання самоконтролю та самокорекції сприятиме формуванню впевненості учня в собі.

Аналіз останніх досліджень і публікацій. Питання теорії та практики використання інноваційних технологій навчання на заняттях ставали предметом досліджень багатьох науковців. Зокрема, ґрунтовне відображення цієї проблематики представлене в роботах В. Мадзігона, В. Лапінського, Ю. Дорошенка, В. Волинського, О. Красовського, О. Чорноус, Т. Якушиної та інших науковців. Зазначені автори окреслили теоретичні засади створення електронних підручників та педагогічні аспекти використання цих підручників під час навчання.

Н. Семенів, Г. Шелехова, Л. Скуратівський, І. Радченко та інші дослідники розробили лінгводидактичні засади фрормування й використання інорормаційних технологій на уроках української та зарубіжної літератури [4]. Таким чином, більшість розвідок стосовно застосування мультимедійних технологій у ході опанування літератури стосується переважно навчання у школі, однак спектр проблем упровадження мультимедійних технологій в освітній процес поступово стає ширшим. Так, питання використання мультимедійних технологій із метою розроблення навчальних матеріалів до створення цілісної концепції побудови освітніх програм у сорері освітньої мультимедіа, підготовки фрахівців різних рівнів відповідно до особливостей цього напряму, фрормування нових засобів навчання через використання цих технологій залишаються невисвітленими в науковій літературі, що й зумовлює актуальність порушення цієї проблематики.

Метою роботи $€$ визначення й теоретичне обґрунтування педагогічних умов застосування мультимедійних засобів під час викладання української та зарубіжної літератури, а також зазначення вправ і завдань для успішного засвоєння теоретичного матеріалу.

Виклад основного матеріалу. Ідея виникнення технології мультимедіа лежить в основі концепції організації пам'яті «MEMEX», яка була запропонована ще в 1945 році американським ученим Ван Нівером Бушем. Цієї концепцією передбачався пошук інформації відповідно до сутності їі змісту, а не за офіційними ознаками, серед яких - індекси, номери, оформлення за алфавітом [3, с. 17]. Ідея цієї концепції спочатку відображалася через спосіб комп'ютерної реалізації у вигляді гіпертекстової системи, тобто системи роботи 3 наборами текстових матеріалів. Пізніше відбиттям цієї ідеї стали гіпермедіа, тобто системи, які працюють із наборами графріків, звуку, анімації та відеоматеріалів.

Водночас пік інтересу до цієї концепції припав на кінець 1980-х років. Саме тоді спостерігалася тенденція до застосування мультимедійних технологій у гуманітарних науках. При цьому доцільно вказати на зв'язок 3 ім'ям Білла Гейтса, адже йому належить ідея створення та досить успішної реалізації мультимедійного продукту на практиці з використанням при цьому службової музейної інвентарної бази даних, у яку входить використання зображень, анімації, звуку та гіпертекстової системи [5, с. 23].

Саме такий продукт дав змогу поєднати в собі три основні принципи мультимедіа: принцип подання інорормації з використанням при цьому комбінації декількох сприйманих людиною середовищ, принцип наявності декількох сюжетних ліній у властивостях продукту та принцип художнього дизайну інтерфейсу і навігаційних засобів [5, с. 24].

Упровадження мультимедійних технологій у навчальний процес $є$ однією з ключових компонент професійної діяльності сучасного педагога. Це пояснюється тим, що зміст дидактичних можливостей мультимедійних технологій дуже різноманітний. Так, мультимедійні технології розрізняють за такими критеріями: 1) фрормою подання інорормації; 2) типами навчальних завдань; 
3) особливостями фрормування навчального середовища, у якому забезпечується переорієнтація здобувача освіти на певний уявний простір і певні життєві ситуації; 4) особливостями забезпечення швидкого зворотного зв'язку; 5) значними можливостями діалогізації навчального процесу; 6) широтою індивідуалізації навчального процесу; 7) особливостями використання основних і допоміжних впливів на навчальний процес; 8) масштабністю поля самостійності; 9) масштабністю застосування ігрових прийомів; 10) значними можливостями відтворення ситуацій навчальної діяльності, зокрема предметнозмістової ситуації, предметно-операційної ситуації та рефрлексивної ситуації; 11) активізацією навчальної роботи здобувачів освіти, особливостями посилення їх ролі як суб'єктів навчальної діяльності [10, с. 48].

Так, упровадження мультимедійних технологій у навчальний процес, на думку О. Бондаренко, В. Імбер, І. Радченко та інших науковців, дасть змогу досягти таких результатів: 1) підвищити рівень інформативності та репрезентативної цінності матеріалу, що використовується в навчальному процесі; 2) стимулювати когнітивні процеси (зокрема, процеси сприйняття та усвідомлення інорормації); 3) підвищити рівень мотивації здобувачів освіти до оволодіння знаннями, уміннями й навичками в результаті засвоєння навчального матеріалу; 4) пришвидшити розвиток навичок у здобувачів освіти в напрямі спільної роботи та колективного пізнання; 5) сорормувати у здобувачів освіти прагнення до засвоєння нових інфрормаційних технологій та застосування їх у проходженні навчальної практики; 6) залучати в навчальний процес різноманітні матеріали з реальної педагогічної практики, що своєю чергою дасть можливість органічно поєднати теоретичний і практичний складники педагогічної підготовки, яку проходять здобувачі освіти, поглибити професійну готовність цих здобувачів до здійснення в перспективі професійної діяльності; 7) удосконалити рівень професіоналізму викладачів, які викладають педагогічні дисципліни, за рахунок посилення вимог до процесу проєктування навчального заняття з використанням на цій основі низки інформаційних технологій [8, с. 14].

Розглянувши ключові функції мультимедіа, О. Бондаренко стверджує, що найдоцільніше класиорікувати мультимедійні технології так:

1) презентаційні мультимедійні технології, які використовуються для представлення нового навчального матеріалу;

2) імітаційні мультимедійні технології, які використовуються для тренування здобувачів освіти (основними елементами такого тренування $€$ постановка завдань, що орієнтовані на аналізування педагогічної ситуації, та фрормування на цій основі вмінь приймати оптимальне рішення або виробляти оптимальну стратегію подальших дій);

3) контрольні мультимедійні технології, які використовуються для контролювання процесу засвоєння здобувачами освіти навчального матеріалу;

4) інорормаційно-довідкові мультимедійні технології, які використовуються для надання здобувачам освіти необхідної теоретичної інфрормації в контексті їхньої самостійної роботи [1, с. 10].

Отже, на заняттях $з$ української та зарубіжної літератури доцільно використовувати такі різновиди мультимедійних технологій: а) мультимедійні презентації для комплексного подання теоретичного матеріалу, а також для повторення, узагальнення й систематизації зазначеного матеріалу; б) мультимедійні технології, які дають змогу ефективно організовувати практичну діяльність здобувачів освіти; в) мультимедійні засоби, що націлені на забезпечення ефективної самостійної роботи здобувачів освіти з літературою; г) мультимедійну інформацію, що є інструктивним та ілюстративним матеріалом для опанування мовних норм і їх втілення в мовленнєву практику в позакласній роботі 3 літератури.

3 огляду на дидактичні потреби й вимоги навчальної програми вчителі повинні обрати таку фрорму подачі інорормації, яка відповідатиме меті та типу заняття. Так, досить часто подача інформації відбувається через мультимедійну презентацію. Мультимедійна презентація являє собою багатофрункціональний наочний інструмент, що дає змогу подати широкий спектр текстової, графрічної, звукової та фротоінфрормації [9, с. 132].

Упровадження мультимедійних презентацій у навчальний процес $є$ невід'ємною складовою частиною роботи в ході вивчення літератури. Завдяки цьому значно підвищується рівень ефективності навчання. Застосування мультимедійних технологій у навчальному процесі дає можливість створювати інформаційний та візуальний образ об'єкта, що досліджується. Так, поширеними на заняттях 3 української і зарубіжної літератури мають стати лекційні презентації, які повинні створюватися за допомогою програми PowerPoint. Мультимедійне забезпечення лекційного курсу дасть змогу покращено активізувати роботу здобувачів освіти, а також підвищити рівень мислення й комунікативні здібності в соціальній практиці. Варто зазначити вплив мультимедіа на підвищення інформативності та ефрективності лекцій, зокрема у процесі пояснення нового навчального матеріалу. Це своєю чергою впливає на підвищення динамізму й виразності поданого матеріалу. Залежно від мети створення й використання презентацій їх можна класифікувати на демонстраційні, систематизуючі та дослідницькі. 
Урок літератури можна умовно назвати уроком образного бачення світу. Через уроки літератури пробуджується уява, франтазія учнів, підвищується розвиток їхніх розумових і пізнавальних здібностей, фрормується особистість кваліфікованого читача. Мета сучасного уроку української та зарубіжної літератури полягає не в нагромадженні знань, а в пошуковій діяльності, що спрямована на формування вмінь і навичок стосовно орієнтації в інорормаційному середовищі.

Наприклад, у процесі вивчення балади Адама Міцкевича «Альпухара» (з поеми «Конрад Валленрод») учні одержують безліч можливостей, зокрема: можливість відтворення в уяві літературного образу Альманзора та бачення того, яким він може бути в реальності; можливість вистежувати на карті маршрути походів цього персонажа; можливість здійснювати віртуальну подорож до палацу Альгамбра; можливість подорожувати гористою місцевістю Сієра-Невада в Іспанії.

Досить значне враження на учнів справляють навчальні документальні фрільми. Особливе місце серед таких фрільмів посідають фрільми, створені на основі реальних історичних орактів, розповідей про картини, що створені за жанрами літературних творів. Варто зазначити, що урок літератури це водночас урок мистецтва.

Використання мультимедіа на уроках літератури дасть можливість здійснювати таку діяльність: 1) показувати репродукції картин і портрети письменників; 2) проводити віртуальні екскурсії сучасними музеями світу; 3) працювати з різними видами карт; 4) проводити словникову роботу; 5) краще вивчати алгоритм поведінки літературного героя; 6) працювати з різними уривками, зокрема уривками з фрільмів, мульторільмів; 7) прослуховувати твори тощо.

Використання презентації на уроках чи лекціях дасть змогу як учителям, так і здобувачам освіти краще ілюструвати їхні доповіді й повідомлення. Застосування цієї технології на уроці передбачає також те, що учні повинні обов'язково вести записи в робочих зошитах. Отже, презентації не відміняють традиційну методику підготовки та проведення уроків, проте їх використання дає можливість полегшити та активізувати технології проведення уроку.

Варто зазначити, що доцільне також використання презентацій на уроках аналізу тексту. Роль презентації у проведенні такого уроку полягає в реалізації інтегративного підходу до навчання.

Досить часто на уроках використовується проблемно-дослідний підхід до навчання. Використання презентацій на таких уроках - це більш потреба, ніж можливість. Так, на слайдах презентації можна представити завдання уроку та висновки, зокрема проміжні, а не додатковий матеріал, як робиться зазвичай. Зіставлення аудіо- й відеоматеріалів дає змогу учням краще аналізувати текст. Використання презентацій на уроках сприяє кращій підготовці уроку та узагальненню результатів, отриманих у підсумку роботи на ньому. Основне завдання проведення уроку полягає в зібранні спостережень, що отримуються в контексті аналізу.

На всіх типах уроків презентації повинні бути розроблені вчителем. Однак у процесі створення презентацій не виключається роль учня чи учнів. Так, учень або колектив учнів також можуть бути авторами презентацій. Такі презентації є підсумковими роботами за засвоєними темами.

Отже, здобувачі освіти у процесі навчання набувають нових компетенцій, наприклад тих, що зазначені в Державному стандарті освіти, зокрема: 1) уміння проводити узагальнення, аналіз і систематизацію інорормації відповідно до потрібної теми; 2) уміння працювати в колективі; 3) уміння шукати інорормацію в різних джерелах; 4) комунікативної компетенції; 5) усвідомлення користі від одержаних знань і набутих умінь.

Під час роботи з презентаціями використовується індивідуальний підхід до навчального процесу. Так, більш активним стає процес соціалізації та самоствердження особистості, глибше розвивається історичне й науково-природне мислення.

Висновки. За результатами дослідження встановлено, що використання мультимедійних засобів у навчальному процесі має такі ключові цілі:

1) зростання пізнавального інтересу здобувачів освіти до цих предметів, а також до якісно нового рівня використання наочних матеріалів на уроках;

2) зростання продуктивності уроку;

3) формування міжпредметних зв'язків;

4) покращення організації проєктної діяльності учнів у ході створення навчальних програм під керівництвом учителів інорорматики та української й зарубіжної літератури;

5) логічний виклад навчального матеріалу;

6) покращення взаємовідносин учнів і вчителя.

3'ясовано, що нині варто залучати здобувачів освіти до активної навчальної співпраці.

\section{БІБЛІОГРАФІЧНИЙ СПИСОК:}

1. Бондаренко О. Дидактичні умови застосування мультимедійних технологій у процесі навчання педагогічних дисциплін студентів педагогічних університетів : автореф. дис. ... канд. пед. наук : 13.00.04 «Теорія і методика профресійної освіти» ; Черкаський національний університет імені Богдана Хмельницького. Черкаси, 2010. 20 c.

2. Дидактичні основи створення аудіовізуальних електронних засобів для середньої загальноосвітньої школи : монограсрія / В. Волинський, О. Красовський, О. Чорноус, Т. Якушина. Київ : Педагогічна думка, 2013. 304 с.

3. Гриценко В., Манако А. Педагогическое проектирование электронных учебников и дистанционных 
курсов, поставляемых через Интернет : учебное пособие. Киев : ООО «Витус», 2002. 123 с.

4. Імбер В. Педагогічні умови застосування мультимедійних засобів навчання у підготовці майбутнього вчителя початкових класів : автореф. дис. ... канд. пед. наук : 13.00.04 «Теорія і методика професійної освіти» ; Вінницький державний педагогічний університет імені Михайла Коцюбинського. Вінниця, 2008. 20 c.

5. Інформаційні технології мультимедіа в сучасному суспільстві. Аналітичний огляд: інструменти, застосування, перспективи. URL: http://referat-ok. com.ua/work/informacijni-tehnologii-multimedia/ (дата звернення: 05.11.2021).

6. Манако А. Еволюція та конвергенція інформаційних технологій підтримки освіти та навчання. Нові інфрормаційні технології в освіті для всіх: навчальні середовища : збірник праць VI міжнародної конфреренції, М. Київ, 22-23 листопада 2011 р. Київ : МННЦ, 2011. С. 20-35.

7. Обрізан К. Програмні засоби навчального призначення. Інфрорматизація середньої освіти: програмні засоби, технології, досвід, перспективи / за ред. В. Мадзігона, Ю. Дорошенка. Київ : Педагогічна думка, 2003. С. 156-165.
8. Радченко І. Майстер-клас: мультимедійні жанри. Українська мова й література в середніх школах, гімназіях, ліцеях та колегіумах. 2008. № 8. C. 8-17.

9. Синиця М. Використання мультимедійних технологій у навчальному процесі ВН3 як засіб формування педагогічних знань. Профресійна педагогічна освіта: становлення і розвиток педагогічного знання : монографрія / за ред. О. Дубасенюк. Житомир : Вид-во ЖДУ імені Івана Франка, 2014. С. 418-438.

10. Удовиченко Л. Теорія і технологія вивчення художніх образів-персонажів у курсі зарубіжної літератури старшої школи : монограсрія. Київ : Інтерсервіс, 2020. 352 c.

11. Хижнякова В. Використання мультимедійних засобів навчання під час викладання курсу «Українська мова (за професійним спрямуванням)». Науковий вісник Міжнародного гуманітарного університету. Серія «Філологія». 2016. № 22. С. 48-50.

12. Яловенко С. Мультимедійні засоби навчання на уроках української мови та літератури. URL: http://yalovenko.ucoz.com/publ/multimedijni_zasobi_ navchannja_na_urokakh_ukrajinskoji_movi_ta_ literaturi/1-1-0-5 (дата звернення: 05.11.2021). 